\title{
Jacques Ferron: transcending solitudes
}

\author{
Le Cabinet du docteur Ferron \\ A film by Jean-Daniel Lafond \\ National Film Board of Canada; 2003 \\ 82 min. French, with English subtitles
}

J acques Ferron (I92I-I985), a general practitioner, was born in Louiseville, in Maskinonge County, Québec. He was a prolific and talented writer, celebrated in his native province but a little-known figure for the rest of Canada, despite extensive translations of his works. This documentary film, although biographical in nature, is constructed in a manner that suffuses itself with the mood, spirit and soul that animate Ferron's writings. The narrator recites fragments from various works, which are dramatized and interposed with interviews, archival footage and re-enactments of situations from real life.

The central focus is the medical office (le cabinet), where Ferron did most of his writing, usually after hours but sometimes in between seeing patients. The office represents a metaphorical as well as physical space, a locus of work and a source of intimate inspiration for the writer. Ferron states that the writer needs solitude to become intimate with his subject matter, solitude as sacrifice but also as necessary discipline.

I've always worked alone in total secrecy, my writing projects are a part of my solitude, they stand for what I hold most intimate.

We are given to understand early in the film that there is a seamless connection between Ferron the medical

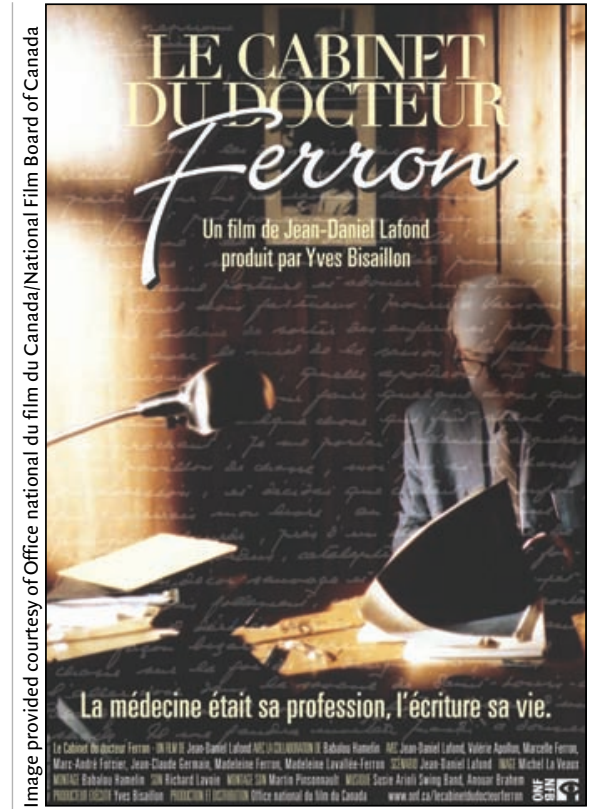

man and Ferron the writer, both parts nurturing each other.

I always wrote as a doctor and practised medicine as a writer.

But the connection is not unproblematic, and it gradually becomes apparent that the equilibrium will be undone by the end of his life.

Lafond starts by giving us glimpses of Ferron's childhood, in particular the death of his beloved mother from tuberculosis when he was only ro years old. On her deathbed she made the young Jean-Jacques promise "not to think of himself as better than others" and to drop the first part of his name. His sister recalls the painful moment when her mother expired. All the other family members were together crying, whereas young Jacques stood apart from them, seemingly emotionless, in the doorway. We hear Ferron evoke his mother's memory in an excerpt from a first-person novel, Les confitures de coings (Quince Jam), in which the narrator describes canoeing on a river as a young boy. The child's river is his genesis but also hides the mystery of his mother's smile behind dangerous falls.

Young Jacques is sent away to a series of boarding schools, one of which is Collège Jean-de-Brébeuf, a private Jesuit college for the French-speaking Canadian élite; one of his classmates is future prime minister of Canada, Pierre Elliott Trudeau. When Ferron is 26 years old, his father, after a failed business venture, commits suicide on the anniversary of his wife's death. Ferron comments later in his life that he thinks his father is courageous, but his meaning is ambiguous.

We are not told why Ferron decides on the medical profession. He graduates in I945, and we then see him working as a country doctor in the Gaspé Peninsula, where he is paid next to nothing but survives on a meager government stipend. Two years spent in contact with a rugged rural population confirm for him that he must become a writer. In a letter to his sister Marcelle, the painter, he asserts:

Literature is the passion of my life, genius is a vital necessity and art a great adventure.

Ferron will draw inspiration from his Gaspé experiences. His contes, or tales, are fictional accounts based on the real lives of ordinary people struggling with day-to-day survival. Humorous, at times fantastical, and 
almost always with an ironic twist, these stories establish his reputation. Ferron's Contes du pays incertain (included in Selected Tales of Jacques Ferron) earned the $1_{9} 62$ Governor General's Award for Literary Merit (French fiction).

The young Ferron is a socialist and, like many Québec intellectuals, a vociferous critic of the Duplessis "régime," the provincial government of the time. As a result of his political actions, his stipend is revoked and he is forced to leave the Gaspé area. the plight of psychiatric patients in Montréal's mental institutions, Ferron becomes an outspoken critic of established psychiatry at a time when the standard treatment of many chronically ill patients consisted of combined frontal lobotomy, shock treatment and major tranquilizers. For I6 months in 1970/7I, he toiled on the female patient wing of Saint-Jean-deDieu (now Centre hospitalier LouisHippolyte-Lafontaine), while still maintaining his cabinet and continuing to impose on himself a gruelling

\section{I always wrote as a doctor and practised medicine as a writer.}

Ferron goes to Montréal, where he sets up practice in the poor suburb of Ville Jacques-Cartier with his brother Paul, also a general practitioner. He produces several successful novels, sends a steady stream of letters and opinion pieces to journals and newspapers, starts a voluminous correspondence with friends and other authors both inside and outside of Québec, and becomes more deeply involved in politics.

In 1963 , by now a confirmed separatist, he forms the Rhinoceros Party to poke fun at federal politics and to promote the use of humour, as opposed to violence, to achieve political change. During the October Crisis in I970, Ferron is chosen to mediate between the government and the FLQ (Front de Libération du Québec), a sign of the trust placed in him by both sides. Some FLQ members had kidnapped Québec Labour Minister Pierre Laporte. Laporte's body was found days later. After the October Crisis, Ferron would boldly assert that the federal government itself fomented the crisis, knew all along where the kidnappers were and could have averted Laporte's death.

For a physician - and particularly a psychiatrist - one of the most moving parts of the film comes near the end, when Lafond takes us inside the world of the "mental asylum," a world Ferron knew well. Deeply interested in publication schedule of at least one book per year.

The theme of madness - its nature, its function - preoccupies him more and more. He writes of le temps mort (the dead time) of the asylums and of how psychiatric patients speak but are not heard (Les roses sauvages, Le pas de Gamelin, Rosaire). He wants to restore a humanistic psychiatry, in which the meaning behind patients' symptoms must be interpreted in a way to make sense of their lives. However, like the mythical Icarus, he is flying too close to the sun. He identifies strongly with his patients and spends years attempting to write what he calls his "great book on madness." Of all his books it is the hardest for him to write, and he will not finish it. When he fails, he believes he has come to the end of his creativity, and a profound moral, spiritual and personal crisis ensues.

Ferron needs help. He is put under the care of a psychiatrist for his suicidal tendencies but, just as the space between doctor and patient has collapsed, so has the space between doctor and writer. He writes L'Exécution de Maski (The Execution of Maski). Maski is the name of Ferron's alter ego, both writer and doctor, whom he has decided to kill off. As they have become inseparable, the only logic is suicide. Maski half-derisively calls Ferron notaire (notary), a reference to the profession of Ferron's father.
As Jack Gilbert suggests in his poem about Icarus, Failing and Flying, ${ }^{1}$ Ferron's "failure" should be seen as the end of his triumph rather than a repudiation of all he stood for. Ferron was a writer of imagination, humour and immense compassion, a courageous traveller, able to crisscross easily the worlds of medicine, literature and politics. Whether he engages us as a writer, doctor or polemicist, it is always to reaffirm our humanity and to restore human dignity where it has been lost. Lafond's film is an excellent introduction to Ferron, the writer and the man. Informative and moving, it encourages us to discover for ourselves the enchantment of reading Ferron's contes.

\section{Normand Carrey}

Psychiatrist

Halifax, NS

Acknowledgements: I sincerely acknowledge my gratitude to Dr. Betty Bednarski, professor of French Literature at Dalhousie University, Ferron scholar and translator, for her suggestions and revisions of this article.

\section{REFERENCE}

I. Gilbert J. Failing and flying. In: Refusing heaven. Toronto: Alfred A. Knopf Canada; 2005.

The film Le Cabinet du docteur Ferron was shown in Halifax on Apr. 25, 2006, as part of "Jacques Ferron, Physician-writer," a full-day symposium celebrating Ferron's writing and medical practice. The travelling exhibition was presented by La Société des Amis de Jacques Ferron in partnership with Dalhousie University's Medical Humanities Program and Department of French.

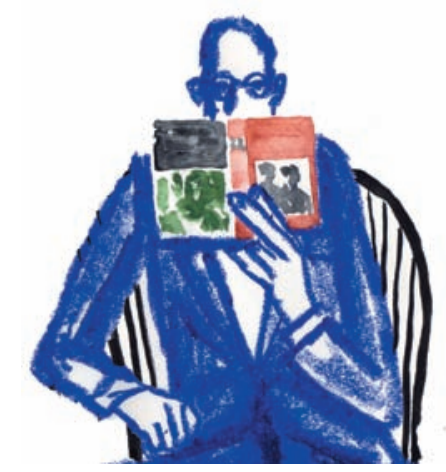

